\title{
Citizenship, Ethnicity, History, Nation, Region, and the Prespa Agreement of June 2018 between Macedonia and Greece
}

\begin{abstract}
The agreement reached at Lake Prespa on 17 June 2018 between Greece and Macedonia should be welcomed, insofar as it promises to end the Greek blockade - in any case unnecessary - of Macedonia's accession to the European Union and to NATO. Yet conceptually, the author argues, the agreement's text is explosive, having been crafted to fundamentally confirm and consolidate a radical 'otherness' of the two parties involved (that is, Greece and Macedonia), encompassing their populations and histories. Any expert tasked with supervising the re-writing of history textbooks in the spirit of this agreement, as stipulated therein, will quickly find it impossible to reconcile the definitions and concepts put forth there with the methodological and theoretical knowledge about the need to de-essentialize and de-construct 'ethnicity', 'history', 'culture', 'nation', etc. This knowledge has been the basic standard in international scholarly debates over at least the last thirty years.
\end{abstract}

Stefan Rohdewald is Professor of Southeast European History at the Justus Liebig University, Gießen, where he leads the priority research programme 'Transottomanica', funded by the German Research Foundation, and directs a project on 'Macedonia as a Landscape of (Dis-) Integration' within the LOEWE research cluster 'Conflict Regions in Eastern Europe'.

Almost any solution to the harmful and unfounded Greek blockade of the diplomatic future of Macedonia would be desirable-maybe even the proposal which evolved this year on the shores of Lake Prespa regarding the naming of the Republic of Macedonia in a way acceptable to all its neighbours. Greece and Macedonia have fiercely disputed the 'name issue' since the breakup of Yugoslavia in 1991. Since 1995, the nations which have refused to use the constitutional name 'Republic of Macedonia' have instead referred to the country as the 'Former Yugoslav Republic of Macedonia' (FYROM).

In the following, I draw attention both to some major presuppositions implied by or explicitly formulated in the text of the agreement, and to critiques. However, as there is effectively not much consensus locally about the problem in question, I also explain why it may make sense to acquiesce to any step which gives the Macedonian and the Greek governments and populations 
an opportunity to agree on something, even the far-from-perfect agreement made at Lake Prespa. This possibility has been made plausible by the leftist or/ and social democratic governments led by Alexis Tsipras in Athens and Zoran Zaev in Skopje. For the first time in many years, governments with analogous political outlooks rule concurrently in the two neighbouring countries. Thus, a rare window of opportunity opened. The agreement's main problem, as I see it, is that it not only tackles the 'name issue' but tries to 'solve' much more, in fact attempts to achieve the impossible. Article 7 reads (all italics are mine):

'1. The Parties acknowledge that their respective understanding of the terms "Macedonia" and "Macedonian" refers to a different historical context and cultural heritage.

2. When reference is made to the First Party, these terms denote not only the area and people of the northern region of the First Party, but also their attributes, as well as the Hellenic civilization, history, culture, and heritage of that region from antiquity to present day.

3. When reference is made to the Second Party, these terms denote its territory, language, people and their attributes, with their own history, culture, and heritage, distinctly different from those referred to under Article 7(2).

4. The Second Party notes that its official language, the Macedonian language, is within the group of South Slavic languages. The Parties note that the official language and other attributes of the Second Party are not related to the ancient Hellenic civilization, history, culture and heritage of the northern region of the First Party.' ${ }^{1}$

As is obvious here, article 7 of the Lake Prespa agreement between the Greek and Macedonian governments implicitly denotes Macedonian - a 'South Slavic language' - to be the only relevant language. However, the constitution of the Republic of Macedonia allows other languages to be declared official, too. The mention of 'territory, language, people and their attributes, with their own history, culture, and heritage, distinctly different' from that of others evokes some homogenous Macedonian, southern Slavic nation-state, probably to garner support for the agreement among the opposition in Skopje, the 'Internal Revolutionary Macedonian Organization-Democratic Party for Macedonian National Unity' (Vnatrešna Revolucionerna Makedonska Organizacija-Demokratska Partija za Makedonsko Nacionalno Edinstvo, VMRO-DPMNE), which is largely opposed to making any concessions to Greece. At the same time, such phrasing aligns with the outlook of the right-wing opposition in Greece, which sees confirmed its imagination of Hellenic Greece as monolingual, monocultural, monodenominational, etc., and, above all, as a homogenous nation-state with

${ }^{1}$ Final Agreement for the Settlement of the Differences as Described in the United Nations Security Council Resolutions 817 (1993) and 845 (1993), the Termination of the Interim Accord of 1995, and the Establishment of a Strategic Partnership between the Parties, web portal 'Virtual Macedonia', https://vmacedonia.com/politics/macedonia-greece-agreement.html. All internet sources were accessed on 8 October 2018. 
an alleged historical continuity that stretched back to antiquity - a narrative which excludes the Slavic, Muslim, and Albanian citizens of today's Greece, as well as Greece's Ottoman past (among other things). ${ }^{2}$

This article 7, like the entire text of the agreement, is quite bitter proof of the negligible effect of scholarly discussions on policymaking. The concepts used explicitly and implicitly with regard to ethnicity, nation, and other adjacent concepts are nowhere in evidence. Yet for at least the last thirty years, scholars have been deconstructing modern nations as 'imagined communities' (Benedict Anderson) and their national master narratives as myths. ${ }^{3}$

\section{Ethnicity}

To be sure, in older academic perspectives 'ethnicity' was seen as something primordial, static, durable, and essentialist, to be observed with alleged objectivity through characteristics such as language, customs, or genealogical origin. Seen from this angle, to possess Slavic ethnicity it would be sufficient, for example, to speak a Slavic language or to be born to parents who did. In the academic approaches of the last thirty-plus years, though, 'ethnicity' has come to be defined differently. Now, the minimalist definition of all forms of collective identity, 'ethnicity' among them, includes an allegiance of an individual to a larger social group. The ethnic belonging of individuals thus depends on self-perception. What is more, this allegiance needs not be clear-cut or exclusive. It can be multiple, heterogenous, hybrid, even just imagined. 'Ethnicity', thus conditioned by temporal and spatial social contexts, has been deprived of any essentialist quality. Today, the concept is understood as a social practice, which has to be (re-)produced in social situations in order to exist-and this by definition includes the option of 'ethnicity' being changed or replaced.

This approach has proved useful not only when attempting to understand individual adherences to social groups in the twenty-first century. It is also valid for any moment that 'ethnicity' is documented in historical sources. Ethnic labels

2 For the Greek side of the Macedonian story cf. Adamantios Skordos, Griechenlands Makedonische Frage. Bürgerkrieg und Geschichtspolitik im Südosten Europas, 1945-1992, Göttingen 2012.

3 Cf. George Margaritis, Wiedergeburt aus dem Geist der Antike, in: Martina Flacke, ed, Mythen der Nationen. Ein europäisches Panorama, Munich, Berlin 1998, 152-173. On the Greece-Macedonian entanglements discussed here cf. Victor Roudometof, Collective Memory, National Identity, and Ethnic Conflict. Greece, Bulgaria, and the Macedonian Question, Westport/CT 2002; Keith Brown, The Past in Question. Modern Macedonia and the Uncertainties of Nation, Princeton 2003; Nick Anastasovski, Contestations over Macedonian Identity, 1870-1912, Melbourne 2005; Stefan Rohdewald, Götter der Nationen. Religiöse Erinnerungsfiguren in Serbien, Bulgarien und Makedonien bis 1944, Vienna et al. 2014. 
used in texts from late Roman antiquity have been contextualized as existing next to other identities, as 'free' or 'enslaved', 'citizen' or 'soldier'. 4

In an analogous way it has been argued that during the early Middle Ages (mainly new) identities, and not necessarily peoples, spread-and thus parts of the populations living in the Avar Empire used Slavic as a lingua franca and turned Slavic. From this point of view, the so-called Migration Period does not signify that there were massive migrations of allegedly homogenous peoples. ${ }^{5}$ This revision shows how current historical research focuses on the social practice of becoming and then being Slavic as a social habitus, making reference to Pierre Bourdieu's well-known concept. ${ }^{6}$

Such an approach would be very useful if applied to the early history of the historical region of Macedonia. It would allow the following reasoning: An individual with a declared identity as Slavic might very well be somebody whose ancestors possessed different self-definitions, be they Thracian, Hellenic, or Roman. Of course, this does not transform Orpheus, rather mythical in any case, into a Bulgarian, as is sometimes claimed in Bulgaria - but why should today's Bulgarians not claim to be partially of Thracian ancestry, placing it beside their Slavic and (Turkic) proto-Bulgarian ancestry? The same would then be true for any of today's inhabitants of the Macedonian region, including Albanians: They, too, claim a linkage to Alexander the Great, who has been venerated in a large conglomerate of sources in a transepochal framework that includes Catholic and Muslim texts alike. ${ }^{7}$ In Muslim contexts, Nizami Ganjavi (1141-1209), one of the greatest romantic epic poets in Persian literature, wrote Eskandar-Namā, one of the many Alexander romances, based on Islamic myths about Alexander the Great and appropriating him as a hero.

Such narratives have been popular since antiquity in Latin, Armenian, Georgian, and Syriac translations and versions in an obviously rather large region and of course not just in Greek. More directly linked to the Macedonian region are the writings of Evliya Çelebi: The most important Ottoman travel writer honoured 'Alexander the Great' (İskender-i kübrā) in the mid-seventeenth century by mentioning him as the ruler when the city of Elbasan (in present-day Albania) was founded, allegedly by Philip the Greek, and soon inhabited by philosophers and sorcerers, 'causing it to flourish'. Here, Alexander was part of

4 Walter Pohl, Die Völkerwanderung. Eroberung und Integration, Stuttgart et al. 2002, 22; and see also 206-212. Pohl had already taken this approach in the 1980s, cf. Walter Pohl, Die Awaren. Ein Steppenvolk in Mitteleuropa 567-822 n. Chr., Munich 1988.

${ }^{5}$ Florin Curta, The Making of the Slavs. History and Archaeology, New York 2001.

${ }^{6}$ Cf., for example, Danijel Dzino, Becoming Slav, Becoming Croat. Identity Transformations in Post-Roman and Early Medieval Dalmatia, Leiden, Boston 2010, 13; Pierre Bourdieu, Raisons pratiques. Sur la théorie de l'action, Paris 1994.

7 Cf. Oliver Jens Schmitt, Skanderbeg. Der neue Alexander auf dem Balkan, Regensburg 2009, 16 and 397. 
a rather integrative description of the population and history of this core region in what was then the Ottoman Empire. ${ }^{8}$

At the beginning of the twentieth century, the sociologist Max Weber defined 'ethnicity' as a belief that individuals belonged to a group with a collective ancestry, and that this belief represented social reality, even if it had no factual correspondence in history. Weber juxtaposed the concept of 'ethnicity' to the allegedly real ancestry of race. ' ${ }^{9}$ 'Rce' of course is no longer an appropriate analytical category; it, too, has been deconstructed or defined as non-existent if not as a discursive imagination.

In short: There probably is no world region and certainly no larger region in Europe that has ever been inhabited by just one group, speaking one and the same language, at any point - the lack of any such homegeneity in micro-, meso-, and macro-regional or temporal frameworks goes as far back as the intermingling of Neanderthals with Homo Sapiens, to mention a finding brought forth by recent DNA research. ${ }^{10}$ Thus, even genetically, the essentialist and immutable definition of 'ethnicity' has been proved wrong and misleading.

\section{A 'Culture, and Heritage, Distinctly Different'}

To claim the historical continuity since the dawn of historical time, or at least since antiquity, of an ethnic group or a nation-state with a 'history' and a 'culture' exclusively its own remains just that: a claim - whether an isolated, individual opinion or a mainstream collective identity in the sense of an 'invented tradition'. All such broader claims have in fact been based on the 'invention of tradition' as they have been developed since the nineteenth century, the beginning of the era of nationalism/nation-states: Such traditions were invented to fit with conceptions of modern statehood in France, Germany, Spain, Russia, Italy, Serbia, and Turkey, to name but a few. None of these claims bear scrutiny for any of these nations, or for Greece and Macedonia, though for them a sociopolitically relevant narrative exists that extends through today.

8 Robert Dankoff / Robert Elsie, eds, Evliya Çelebi in Albania and Adjacent Regions (Kosovo, Montenegro, Ohrid). The Relevant Sections of the Seyahatname Edited with Translation, Commentary and Introduction, Leiden et al. 2000, 160-161. Cf. my analysis in Stefan Rohdewald, Beschreibungen von Uneinheitlichkeit im 'Osmanischen Europa' am Beispiel von Evliya Çelebis Bericht über Albanien und Makedonien, Geschichte in Wissenschaft und Unterricht 68, no. 5/6 (2017), special issue 'Osmanisches Europa' ed. by Markus Koller, 265-277, 271.

9 Max Weber, Wirtschaft und Gesellschaft. Grundriss der verstehenden Soziologie, Tübingen ${ }^{5} 1972,237,234$.

${ }_{10}$ Johannes Krause, Der Europäer ist auch genetisch ein Potpourri, Frankfurter Allgemeine Zeitung, 25 December 2016, http://www.faz.net/aktuell/wissen/der-europaeer-ist-auch-genetisch-ein-potpourri-14560727.html?printPagedArticle=true\#pageIndex_0. 
While this relevance and its consequences have to be acknowledged as part of existing social and cultural realities, any ethnic appropriation of history remains problematic. The claim to have a 'culture, and heritage, distinctly different' from those of one's neighbours is as futile on historical grounds as it is fundamental for any national conception of history. The social anthropologist Fredrik Barth explained how a few particular features were used in social practices to deliminate neighbouring and closely related communities. ${ }^{11}$ The imagination and production of a narrative of a history of one's own are key to such delimination. Academic debates on the construction of otherness, on the cultural practices of negotiating and maintaining difference, have been central since the emergence of the fields of Cultural History and Cultural Studies. The understanding of the concept of culture changed especially in this context: In contrast to older interpretations, where culture was seen as static and confined to one population (Kulturträgervolk) in one clearly deliminated cultural area (Kulturraum), 'the cultural' is now seen as comprising situative connotations of meaning within a framework of discursive and pragmatic procedures or practices. ${ }^{12}$ The use of 'cultural' as an adjective avoids any essentialist imagination of the concept and stresses the procedural, performative aspect of the negotiation and constitution of difference or indifference. ${ }^{13}$ Thus, the speechacts which negotiate cultural meaning in social practices, both in (trans)local or global contexts, have come to stand at the centre of interest, accompanied by a rejection of the presupposition that 'culture' can be understood as something akin to a static container. ${ }^{14}$ The deconstruction of national narratives based on cultural distinctness or exceptionalism or grounded in national myths remains a key matter in both research and politics.

\section{Languages ...}

Characterizing ancient Macedonia, scholars have described its 'several tribes' with 'different origins' and languages, which were united by the socioeconomic

11 Fredrik Barth, Introduction, in: Frederik Barth, ed, Ethnic Groups and Boundaries. The Social Organization of Culture Difference, Long Grove/Ill. ${ }^{71998, ~ 9-38 . ~}$

${ }^{12}$ Karl H. Hörning, Kultur als Praxis, in: Friedrich Jaeger et al., eds, Handbuch der Kulturwissenschaften, vol. 1, Stuttgart, Weimar 2004, 139-151, 139.

${ }^{13}$ Cf. Arjun Appadurai, Modernity at Large. Cultural Dimensions of Globalization, Minneapolis, London 1996, 12; Jürgen Osterhammel, Die Vielfalt der Kulturen und die Methoden des Kulturvergleichs, in: Jaeger et al., eds, Handbuch der Kulturwissenschaften, vol. 2, 50-65; Doris Bachmann-Medick, Cultural Turns. Neuorientierungen in den Kulturwissenschaften, Reinbek 2006, 202.

14 Andreas Reckwitz, Zwischen Hyperkultur und Kulturessenzialismus. Die Spätmoderne im Widerstreit zweier Kulturalisierungsregimes, Soziopolis. Gesellschaft beobachten, 24 October 2016, http://www.soziopolis.de/beobachten/kultur/artikel/zwischen-hyperkultur-und-kulturessenzialismus/; Homi K. Bhabha, The Location of Culture, New York 1994. 
practice of transhumance, that is by nomadic pastoralism focused on the seasonal movement of livestock between fixed summer and winter pastures. Anything ethnically homogenous later ascribed to these societies is a cultural construction. If 'Macedonians in the narrower sense' may have consisted of a group that migrated from Thessaly and spoke an 'Aeolian dialect of Greek', these people were maintaining practices of difference in the upper parts of the ancient region of Macedonia, whereas the inhabitants of the lower lands were considered Thracians. ${ }^{15}$ Ancient Macedonian is thus considered as either a language closely related to ancient Greek, or a dialect thereof. Attic Greek only later became the language of the leading, noble social groups, while the Greeks considered the Macedonians to be barbarians - i. e. quite different from themselves.

Furthermore, before 1800 no one ever considered either 'Hellenic Greece', reaching from Sicily to Bactria in Central Asia, or the Byzantine Empire, reaching from Ravenna to Jerusalem and northern Africa, simply to be homogenous Greek nation-states: They were, like any state or empire before the twentieth century, ethnically heterogenous. Especially the elites, but probably also members of lower social strata, knew and used several languages. Moreover, the vocabularies or grammatical elements in use were not necessarily delimited clearly from each other as different languages. Rather, they were applied in functional and pragmatic ways. A mixture of several languages was spoken, just as German contains many words of direct or indirect Latin origin, English is a mixture of Anglo-Saxon, Norse, and Old French, and Ottoman Turkish worked with Turkish grammar and with Arabic, Persian, and, to a lesser degree, Greek and other languages' vocabulary.

After 1800, nationalist academics 'purified' the French, Greek, Turkish, and Romanian languages from allegedly 'foreign' elements. These examples, once more, makes it obvious that the notion of linguistic homogeneity is utterly artificial. Interestingly, in the context at stake here, the reinvention and attempted prescription of a Greek language that was close to written Byzantine and ancient Greek (katharenousa) failed and in 1976 was superceded by the vernacular (dimotiki) influenced by later historical developments and by languages of historical regional importance, Latin, Venetian Italian, Turkish, or Slavic languages among them.

Historically, the use of multiple languages was the rule in different social contexts, such as family, trade, law, religion, and poetry. And this was the case not only in the Mediterranean region before public schools became common in the nineteenth century. ${ }^{16}$ With the introduction of systems of public schooling,

15 Cf. Heinz Willemsen, Makedonier, in: Holm Sundhaussen / Konrad Clewing, eds, Lexikon zur Geschichte Südosteuropas, Vienna, Cologne, Weimar ${ }^{2} 2016,584-586$.

16 Eric Dursteler, Speaking in Tongues. Language and Communication in the Early Modern Mediterranean, Past \& Present 217, no. 1 (2012), 47-77. 
national literary languages - codified and homogenized by systematic grammars and modern linguistic research, and now possessing a standardized basic vocabulary - began to be taught. The invention of literary canons, populated by writers-turned-national-geniuses such as Dante, Cervantes, Schiller, Goethe, Pushkin, and Shevchenko, fostered such language instruction. The historical region of Macedonia has been a showcase for this development. Here, since the late nineteenth century, fierce competition has characterized the modern institutionalization (through schools), teaching, and propagation of the Bulgarian, Serbian, and Greek languages, as well as these groups' histories and identities. ${ }^{17}$

\section{$\ldots$ and Regions}

If the inhabitants of all the regions of Europe, Asia, and Africa have historically been ethnically heterogenous and have always spoken, at least in part, several languages, then all claims about a territory's alleged ethnic homogeneity - and all actions devoted to reaching this goal-are but expressions of the political agendas of nationalists, be they politicians, historians, or other actors. ${ }^{18}$ The historical region of Macedonia is rather better documented than those other European regions that today construct a legacy dating back to antiquity, such as Illyria, Dalmatia, Thrace, Ionia, or Moesia - or Provence, Tuscany, and many others. The historical region Macedonia was, in antiquity and until the seventh century, comparatively well consolidated as a coherent political space united under several dynasties. Alexander was venerated as the culmination and central figure of this historical period.

In antiquity, lower Macedonia around the city of Salonica was distinct from upper Macedonia on the upper Axos (Vardar) river, and from several other parts of the region. Since the ninth century, though, the region's northern areas began to bear the name of the province of Bulgaria, and instead of becoming part of Thrace they became the province of Macedonia. Thus, the shape (and the naming) of the region became blurred and regained coherence only in the eigteenth and nineteenth centuries. Indeed, the acknowledgment of changes to the ancient region of Macedonia and its only partial historical continuities, which has been substantiated by scholars, lays the groundwork for the most reasonable way to imagine and analyze its local historical and sociocultural contexts: as a node of networks entangled with other contexts and social spaces.

17 Cf. Fikret Adanır, Die makedonische Frage. Ihre Entstehung und Entwicklung bis 1908, Wiesbaden 1979; Stefan Troebst, Das makedonische Jahrhundert. Von den Anfängen der nationalrevolutionären Bewegung zum Abkommen von Ohrid, 1893-2001. Ausgewählte Aufsätze, Munich 2007.

18 Mathias Beer, ed, Auf dem Weg zum ethnisch reinen Nationalstaat? Europa in Geschichte und Gegenwart, Tübingen 2004. 


\section{Citizenship Part A. Political Nation vs Ethnic Nation around 1900}

From the end of the eighteenth century to 1900, the political concept of a people's sovereignty gained ever greater adherence. It came to seem more legitimate than the older concept of dynastic loyalty to a sovereign monarch. However, in the historical region of Macedonia, loyalism in particular to the Ottoman dynasty and constitution was propagated anew and continued to gain support with the Young Ottomans in the second half of the nineteenth century, then in 1908 with the Young Turks. ${ }^{19}$ In the whole of the historical region of Macedonia, Ottoman constitutional loyalism was embraced again for a few - final, and very short-days in 1908 in the hopes that the concept would integrate all ethnic groups as the citizens of a single unified political entity. ${ }^{20}$ The former Ottoman citizen emigré Leon Sciaky, whose autobiography was published in 1946 in the U.S., recalled:

'Greeks, Bulgarians, Turks, Jews, Armenians and Albanians had literally fallen in each other's arms and with tears of joy had embraced and called each other "Brother". The streets and squares had echoed with the jubilant hymns of joy which had arisen from thousands of hearts, and the Te Deum sung in all languages. For, while few indeed among these people, so long kept in political ignorance, understood the meaning of a Constitution, all sensed the significance of freedom. [...] Heretofore unkown Turkish words such as "vatan," fatherland, and others one never before dared utter, were now shouted lustily. Yashasin [sic, S. R.] Hurriet, Adalet, Musavat [Long Live Liberty, Justice, Equality]!'21

But because of the (for now unilaterally) declaration of union of the state of Crete with Greece in 1908 and the ensuing sanctions against Greek merchants in the Ottoman Empire, this consensus soon collapsed. In the final years of the Ottoman Empire, (Young) Turkish, Greek, Serbian, and Bulgarian nationalisms prevailed..$^{22}$

${ }^{19}$ Isa Blumi, Reinstating the Ottomans. Alternative Balkan Modernities, 1800-1912, Basingstoke 2011.

${ }^{20}$ Cf. about Bulgarian Ottomanist loyalism Darin Stephanov, Solemn Songs for the Sultan. Cultural Integration through Music in the Late Ottoman Empire, 1840s-1860s, in: Risto Pekka Pennanen et al., eds, Ottoman Intimacies, Balkan Musical Realities, Helsinki 2013, 13-30; Darin Stephanov, The Ruler and the Ruled Through the Prism of Royal Birthday Celebrations. A Close Look at Two Documents, in: Maria Baramova et al., eds, Power and Influence in South-Eastern Europe. 16-19 $9^{\text {th }}$ Century, Berlin 2012, 263-270; Darin Stephanov, Minorities, Majorities, and the Monarch. Nationalizing Effects of the Late Ottoman Royal Public Ceremonies, 1808-1908, Memphis 2012.

${ }^{21}$ Leon Sciaky, Farewell to Salonica. Portrait of an Era, London 1946, 164-165.

22 Cf. Şükrü Hanioğlu, A Brief History of the Late Ottoman Empire, Princeton 2008; Şükrü Hanioğlu, Preparation for a Revolution. The Young Turks, 1902-1908, Oxford 2010. 
The Balkan Wars of 1912/13 proved to be a significant escalation of nationalist violence and of 'modern warfare' against the civil population, as stated prominently by the report financed by the Carnegie Foundation. ${ }^{23}$ It was precisely in this context that the concept of political allegiance of all groups living in the Macedonian historical region to one state not defined as that of a single ethnic group was formulated and propagated: Intellectuals speaking for this territory's Aromunian population were eager to point out that all groups in this region should aim to live together, in contrast to the claims made by other ethnic groups to be the exclusive owner of any political, desirably autonomous entity. The former approach, explained in a pamphlet called 'Macedonia for the Macedonians', ${ }^{24}$ was entirely different from William Gladstone's formula for the installation of mononational states in the region, as he had written in 1897: 'Why not Macedonia for the Macedonians, as well as Bulgaria for the Bulgarians, and Servia for the Servians?'25 The Aromunian outline of a Macedonian nation that would be politically rather than ethnically based emerged in the aftermath of the disastrous Balkan Wars of 1912/1913, when Bulgarian, Serbian, and Greek nationalists had destroyed any hope of a pluriethnic or plurireligious modus vivendi among the various groups. Remaining the view only of a small minority, it never got close to being realized in the decades that followed.

In contrast to this programme, the 'Bulgarian Macedonian-Adrianopolitan Revolutionary Committees' in 1896 wrote into their constitution their aim to raise 'the consciousness for self-defence among the Bulgarian population' in these regions in order that there be 'one single uprising in all places' ${ }^{26}$ These committees were interested in what they thought of as the Bulgarian part of the population, even though they were formally looking for 'full political autonomy in Macedonia and the region of Odrin [i. e. Edirne, Adrianople, S.R.]' and thus embraced a regional approach, too. Instead, by 1913, national segregation was the aim of almost all the political organizations in the region, except for the formally governing Committee of Union and Progress (Ittihad ve Terakki Cemiyeti, CUP). Thus, citizenship had been conceived, since the establishment of the first

${ }^{23}$ Carnegie Endowment for International Peace, Report of the International Commission to Inquire into the Causes and Conduct of the Balkan Wars, Washington/DC 1914, 1.

24 'Makedonia al Makedoniani. Makedonia konstitucus lore autonoma stato, ube omna nacioni havus la sama imposti, egala yuri ed ube la libereso dil koncienco e di la linguo esus proklamita kom absoluta.' Makedonia al makedoniani. La kulturala societo makedonian rumaniana. Tradukita da Doktoro Popescu-Hagiul (Bukarest), Stockholm 1917, 13.

25 William E. Gladstone, On the Macedonian Question, The Times, 6 February 1897. His suggestion, discussed in the years that followed, was reiterated later in the London Daily News, 15 August 1903, 6.

${ }^{26}$ Ustav na Bălgarskite makedono-odrinski revoljucionni komiteti [printed leaflet without indication of place or date, probably 1896], Okrăžen dăržaven arhiv -Smoljan, f. 30 k, op. 1, a. e. 1, quoted as edited in: Dimităr Kosev et al., eds, Makedonija. Sbornik ot dokumenti i materiali, no. 41, Sofia 1978, 390-391. 
political associations in the late nineteenth century, primarily in terms of ethnic belonging rather than geographical or political affiliation. The Bulgarian and/ or Macedonian revolutionary organizations established at the end of the nineteenth century, as well as analogous Serbian and Greek groups, were leading factors in this development. ${ }^{27}$ But for any part of the region, and especially any city within it, such an approach, which ultimately supported ethnic 'cleansing' and the exchange of populations in order to achieve national homogeneity, was disastrously misguided. It neglected the local population as a whole, including Muslims - or, in the case of Salonica, Jews. Salonica, the largest city and by far the region's most important port, was claimed by Serbians, Bulgarians, Greeks, and Ottoman loyalists and then Turks, despite its Jewish majority until their annihilation during the Shoah. ${ }^{28}$

\section{Citizenship Part B. Political Nation vs Ethnic Nations after 1989}

After the political changes of 1989, and with the independence of the formerly Yugoslav republic of Macedonia in 1991, the concept of citizenship was again chosen to be fundamental to the national and political narrative. ${ }^{29}$ Leading conservative parties such as the aforementioned newly founded party VMRO, co-governing the country between 2006 and 2017, referred to the discourses of the early 1900s and re-produced the narrative of a monoethnic Slavic nation-state. This conception was confirmed in the constitution itself, which stresses that the ethnonational uprising in 1903 in Kruševo was the direct basis for the legitimation of today's statehood. The present Macedonian state was thus defined as

'proceeding from the historical, cultural, spiritual, and statehood heritage of the Macedonian people and their centuries-long struggle for national and social liberty and for the creation of their own state, and particularly from the statehood and legal traditions of the Kruševo Republic [...].'30

${ }^{27}$ Cf. Adanır, Die makedonische Frage; Troebst, Das makedonische Jahrhundert.

28 Mark Mazower, Salonica. City of Ghosts. Christians, Muslims and Jews 1430-1950, London 2004.

${ }^{29}$ Cf. my project 'Macedonia as a Landscape of (Dis-)Integration' within the LOEWE research cluster 'Regions of Conflict in Eastern Europe', investigating the development of the description of the historical region of Macedonia as a region of conflicts around 1900 (researched by Denis Ljuljanović) and the remembrance or references to this context after 1989. The project's website can be found at http://www.konfliktregionen.de/forschung/fallbeispiele/ makedonien. For the interwar period and the Cold War see Stefan Troebst, Die bulgarisch-jugoslawische Kontroverse um Makedonien 1967-1982, Munich 1983; and Stefan Troebst, Mussolini, Makedonien und die Mächte, 1922-1930. Die ‘Innere Makedonische Revolutionäre Organisation' in der Südosteuropapolitik des faschistischen Italien, Cologne, Vienna 1987.

30 Odluka za proglasuvanje na ustavot na Republika Makedonija, http://www.wipo.int/ edocs/lexdocs/laws/mk/mk/mk014mk.pdf, quoted from an official English translation, Con- 
The negotiation of political participation led to conflict in Macedonia, with a population that is more than 30\% Muslim (Albanian, Slavic, and Turkish), soon after the state's establishment in 1991. But such conflict never escalated the way it did in Croatia, Bosnia, and Serbia/Kosovo. During the violent crisis of 2001, Macedonia's international partners helped to establish the Agreement of Ohrid, which has remained the framework for the negotiations concerning the Republic's modus vivendi. ${ }^{31}$ The constitution was changed in the spirit of this agreement: the preamble was enlarged, yet continued to promote a 'national state of the Macedonian people'. Confirmed once more was the dimension of all-encompassing citizenship, rather than the participation of all groups beyond the core group, i. e. the Slavic Macedonians. The 'Macedonian people' thus continued to be implicitly thought as ethnically and religiously homogenous. They are defined as being different from 'other nationalities' living in the republic. The constitution establishes as a

'[...] historical fact that Macedonia is established as a national state of the Macedonian people, in which full equality as citizens and permanent coexistence with the Macedonian people is provided for Albanians, Turks, Vlachs, Roma and other nationalities living in the Republic of Macedonia [...]. ${ }^{32}$

Unlike the Bulgarian constitutional model, for example, the Macedonian constitution conceives of the republic's population not as an integrated Macedonian political nation but rather as a 'Macedonian people' complemented by other 'nationalities'. ${ }^{33}$ There developed nonetheless an understanding that Macedonia represents a common political arena for all its citizens, not least because of ambitions to join the European Union and the conferral of candidate status on the country in 2005. ${ }^{34}$ However, this overarching consciousness that the nation's citizens belong to one common political entity, which to some extent has emerged since 1989, has not been matched with a shared approach to a com-

stitution of the Republic of Macedonia, http://eudo-citizenship.eu/NationalDB/docs/MAC\%20 Constitution\%20(amended\%20by\%20XXX)\%20eng.pdf, 9 .

31 Aktan Hamza, Makedonya-Arnavutluk ilişkilerinde Arnavut sorunu, Üsküp 2006; Blerim Reka, ed, Ten Years from the Ohrid Framework Agreement. Is Macedonia Functioning as a Multi-Ethnic State?, Tetovo 2011.

32 Constitution of the Republic of Macedonia, 9.

33 On the Bulgarian 'ethnic model' Bernd Rechel, The 'Bulgarian Ethnic Model', Europe Asia Studies 59, no. 7 (2007), 1201-1215; Stefan Rohdewald, Die ‘Bewegung für Rechte und Freiheiten' und das 'Bulgarische ethnische Modell'. Funktionen und Grenzen eines politischen Legitimationsdiskurses unter Bulgaren und bulgarischen Türken, in: Katrin Boeckh et al., eds, Staatsbürgerschaft und Teilhabe. Bürgerliche, politische und soziale Rechte in Osteuropa, Munich 2014, 161-178.

34 Stojan Slaveski / Atanaz Kozarev, 'Europeanization' of the Macedonian National Identity, Western Balkans Policy Review 2, no. 1 (2012), 21-38, 26. 
mon history and identity. ${ }^{35}$ Quite the contrary: programmes such as 'Skopje 2014 ' have deliberately sought to hinder such a possibility. ${ }^{36}$ Beyond strong references to Alexander the Great and other figures from antiquity, the project included only orthodox figures. No mention was made, for example, of the heroic Albanian equivalent to Alexander, Skanderbeg, who had actually received the name of the ancient Alexander as a name of honour. ${ }^{37}$ Skanderbeg would indeed have been quite apt in a construction of a comprehensive Macedonian political-rather than ethnic - narrative. To be sure, Albanian Macedonians in Skopje had financed and erected a monument to Skanderbeg back in 2006, and it proved to be important to the repertoire performed with 'Skopje 2014 ' ${ }^{38}$

These separate history politics notwithstanding, the 'national minorities' mentioned in the constitution have been represented in administrative bodies and in the government. However, whereas in 2013 the Human Rights Report listed that nine of the twenty-three members of the Council of Ministers were representatives of minorities, ${ }^{39}$ the 2017 Report states only that 'ethnic Albanians and other ethnic minorities continued to complain of inequitable representation within government and discriminatory practices that excluded them from political participation' ${ }^{40}$ Thus, despite instances of proportionality, the constitutional definition of citizenship has prevented the substantialization of the concept of a multinational state and, more significantly, of a political identity based on the notion of citizens sharing a common state. Slavic politicians understand themselves to be 'ethnic Macedonians' and to be exclusively entitled to represent the

35 Slaveski / Kozarev, 'Europeanization', 35-36; Ulf Brunnbauer, The Implementation of the Ohrid Agreement. Ethnic Macedonian Resentments, Journal on Ethnopolitics and Minority Issues in Europe 1 (2002), 1-24; Holm Sundhaussen, Jugoslawien und seine Nachfolgestaaten 1943-2011. Eine ungewöhnliche Geschichte des Gewöhnlichen, Cologne et al. 2012, 473-477. Cf. Stefan Rohdewald, Türken als Bulgaren und Makedonier, Tataren als Ukrainer, multiethnische Türkei? Politische vs. ethnische Nationsentwürfe nach 1989 im regionalen Vergleich, in: Monika Wingender et al., eds, Mehrsprachigkeit in politischen Umbruchphasen, Wiesbaden 2016, 257-270.

36 Ulf Brunnbauer, Das Projekt 'Skopje 2014'. Oder: Wie ein Land seine Zukunft verbaut, Ostblog, 24 September 2014, https://ostblog.hypotheses.org/255.

37 Cf. Schmitt, Skanderbeg.

38 Cf. Nadège Ragaru, The Political Uses and Social Lives of 'National Heroes'. Controversies over Skanderbeg's Statue in Skopje, Südosteuropa. Journal of Politics and Society 56, no. 4 (2008), 522-555.

39 U.S. Department of State, Country Reports on Human Rights Practices for 2013. Macedonia, http://www.state.gov/j/drl/rls/hrrpt/humanrightsreport/index.htm?year=2013\&dlid $=220304$.

40 U.S. Department of State, Country Reports on Human Rights Practices for 2017. Macedonia, http://www.state.gov/j/drl/rls/hrrpt/humanrightsreport/index.htm?year=2017\&dlid=277191. 
republic of the (ethnically defined) Macedonian people. As a result, they remain reserved vis-à-vis the political representatives of the 'other' nationalities. ${ }^{41}$

The Macedonian Orthodox Church's use of Clement of Ohrid as state and national patron, or of the saints Cyril and Methodius, as happened for example during 2001, was potentially meaningful only for those who identified with a Christian, Orthodox, and ethnically Slavic nation, bypassing the Muslims who make up more than $30 \%$ of the country's population. The national conservative party VMRO-DPMNE supported these sorts of actions by the church, even though this party has governed in several coalitions with parties representing the national minorities. ${ }^{42}$ In a wider regional context, such use of religious lieux de mémoire as a means to mobilize a specific form of national and state identity parallels analogous practices in Greece, Serbia, and Bulgaria. In the latter country, reference is to the same Cyril and Methodius who are invoked in Macedonia. In Bulgaria, however, such practices, jointly performed by the Bulgarian Orthodox Church and leading politicians, are in open opposition to the country's constitution, which defines the nation as a political rather than an ethnic entity, although a special historical role is attributed to the Bulgarian Orthodox Church. ${ }^{43}$

Thus in Macedonia, contrary to what has transpired in Bulgaria, there has been hardly any emergent political discourse to integratively characterize the entire population within the state's territory. To give but a few examples: one of the rare instances of the use of the term 'Turkish Macedonians' occurs in the Turkish language (Türk Makedonyalılar) and refers to the Torbeş, Macedonian-speaking Muslims, or 'Muslim Macedonians'. In fact, this particular text focuses on the topic of 'Macedonian Turks' (Makedonya Türkleri). ${ }^{44}$ Muslim Albanians are somewhat more successful in representing an Albanian identity within the

${ }^{41}$ Slaveski / Kozarev, 'Europeanization', 28.

42 Stefan Rohdewald, Im Schatten ihres Schülers Kliment. Kyrill und Method als Medien nationaler Identifikation und internationaler Anerkennung in der (Teil-)Republik Makedonien im Umbruch, in: Agnieszka Gąsior / Agnieszka Halemba / Stefan Troebst, eds, Gebrochene Kontinuitäten. Transnationalität in den Erinnerungskulturen Ostmitteleuropas im 20. Jahrhundert, Cologne et al. 2014, 88-98; Stefan Rohdewald, Sava, Ivan von Rila und Kliment von Ohrid. Heilige in nationalen Diensten Serbiens, Bulgariens und Makedoniens, in: Stefan Samerski, ed, Die Renaissance der Nationalpatrone in Ostmitteleuropa im 20./21. Jahrhundert, Cologne 2007, 182-217, 207-214.

43 Stefan Rohdewald, Multiple Europäizitäten. Orthodoxie und Islam in politischen öffentlichen Diskursen in Bulgarien nach 1989, in: Alois Ivanišević, ed, Re-Sakralisierung des öffentlichen Raums in Südosteuropa nach der Wende 1989?, Frankfurt/M. 2012, 99-114; Daniela Koleva, Saints Cyril and Methodius. From Christian Sanctity to (Trans)National Memory, in: Gąsior / Halemba / Troebst, eds, Gebrochene Kontinuitäten, 75-87.

${ }_{44}$ Makedonya Türkleri, web portal 'Forum GNC', n. d., http://www.forumgnc.com/turk-tarihi/375350-makedonya-turkleri.html. 
framework of Macedonian state citizenship, ${ }^{45}$ whereas leading politicians among the Muslim Slavs intentionally refer to themselves 'simply' as Macedonians. ${ }^{46}$

Fears of increased Albanian influence, both within the country and allegedly from Albania itself, have guided protests against the new, social democratic government since 2017. These protests recycle the language of the late 1890s and early twentieth century: demonstrators carried the motto 'Freedom or Death' on their posters. ${ }^{47}$ This motto, evoking the discourse of civil warfare within the Ottoman Empire, represents nothing constructive with regard to today's situation. Similarly, there were the bloody protests against Talat Xhaferi's election as an 'Albanian' president of the parliament (the first ever) in April 2017, which was aligned with VMRO-DPMNE's refusal to recognize him in this position. ${ }^{48}$

According to the Ohrid Agreement of 2001 and to the amended constitution, 'any other language spoken by at least 20 percent of the population is also an official language'.$^{49}$ However, only in January 2018 was Albanian acknowledged as an official language on the national (but not the international) level..$^{50}$ Nonetheless, president Ǵorge Ivanov has refused to ratify this law; it has neither been published nor implemented. ${ }^{51}$ The Lake Prespa agreement of June 2018, once more, mentions just 'one official language, the Macedonian language', and does not acknowledge the linguistic, religious, or denominational heterogeneity of the citizens of Macedonia. My guess is that its argument is put forth this way to secure the support of the Slavic Macedonians - yet to no avail, as the recent referendum vividly showed. As political scientist Biljana Vankovska argues: 'The overwhelming majority of ethnic Macedonians [...] are not willing to

45 Jordanka Telbizova-Sack, Die Balkanmuslime zwischen Orient und Okzident, in: Gabriella Schubert / Holm Sundhaussen, eds, Prowestliche und antiwestliche Diskurse in den Balkanländern/Südosteuropa, Munich 2008, 295-310.

46 Jordanka Telbizova-Sack, Eine Identität mit vielen Gesichtern? Die slavischen Muslime Makedoniens, in: Istvan Keul, ed, Religion, Ethnie, Nation und die Aushandlung von Identitäten, Berlin 2005, 47-66.

47 Tensions Rise as Macedonia Protests Continue, BalkanInsight, 28 February 2017, http:// www.balkaninsight.com/en/article/news-02-28-2017.

48 Nationalisten stürmen Parlament in Skopje, Die Zeit, 27 April 2017, https://www.zeit. de/politik/ausland/2017-04/mazedonien-parlament-besetzt-verletzte-nikola-gruevski-zoranzaev-talat-xhaferi.

49 Constitution of the Republic of Macedonia, 9.

50 Macedonia Passes Albanian Language Law, BalkanInsight, 11 January 2018, http://www. balkaninsight.com/en/article/macedonia-passes-albanian-language-law-01-11-2018; Macedonia Passes Law Boosting Albanian Language Status, Radio Free Europe / Radio Liberty, 11 January 2018, https://www.rferl.org/a/macedonia-passes-albanian-language-law/29099285.html.

51 Prezidentăt na Makedonija George Ivanov otkaza da podpiše zakona za upotreba na ezicite, Balgarsko nazionalno radio, 15 March 2018, http://bnr.bg/horizont/post/100945537; Prezidentăt na Makedonija pak blokira albanskija za vtori oficialen ezik, Klub 'Z', 15 March 2018, https://clubz.bg/65427-prezidentyt_na_makedoniq_pak_blokira_albanskiq_za_vtori_oficialen_ezik. 
trade their identity for any foreign-policy reward.' Furthermore, if any section of the population could have been open to the idea, she added, it would have been Macedonia's ethnic Albanians. ${ }^{52}$ Her statement frames the dispute once more in terms of the internal Macedonian contention. Not much seems to have evolved since Arbën Xhaferi of the Albanian Democratic Party (Partia Demokratike Shqiptare, PDSH) wrote in 2001:

'Since 1991, the saddest question for Macedonia has not been its territorial integrity, and neither the name issue in relation to Greece, but rather the question of the incompatibility of the ethnocentric concept of the state with the multiethnic reality in the country. 53

As I see it, a great opportunity was lost at Lake Prespa: the agreement supports the equation of 'ethnic Macedonians' with Slavic Macedonians, thereby excluding the delimination of a political nation that includes Albanian Macedonians, Turkish Macedonians, Aromunian Macedonians, and others. The history of any state in the region, including Greece of course, can potentially be treated as 'a laboratory of transcultural history', rather than as a repeated reiteration of the myth of a monoethnic, monocultural, monolinguistic history. ${ }^{54}$ In fact, the overwhelming support for the Lake Prespa agreement in the 4 October referendum concerning its approval came precisely from the Muslim citizens of Macedonia - while the boycott by the vast majority of the population aptly illustrates the dilemma. ${ }^{55}$ Consequently, it is substantially because of these Macedonian conceptual issues with regard to ethnicity, culture, and language that Greece's demand to have the name of the neighbouring Republic changed is futile to begin with.

A clarification of the nature of the historical region Macedonia would have been sufficient for any sort of agreement. The area has been inhabited for thousands of years by populations that, in terms of their languages, religions, and denominations, have been heterogeneous, and its borders have been blurred. This historical region simply cannot serve as the basis for any of the various

52 Macedonia and Greece Vow to Solve Decades-Old Name Dispute, NBC News, 10 January 2018, https://www.nbcnews.com/news/world/macedonia-greece-vow-solve-decadesold-name-dispute-n836396. Cf. Biljana Vankovska's contributions in recent months to the newspaper Nova Makedonija, https://www.novamakedonija.com.mk/author/biljana-v/.

53 Arbën Xhaferi, Makedonien zwischen Ethnozentrismus und Multiethnie, in: Walter Kolbow / Heinrich Quaden, eds, Krieg und Frieden auf dem Balkan - Makedonien am Scheideweg? Chancen, Herausforderungen und Risiken des Aufbruchs nach Europa, Baden-Baden 2001, 36-43, 42.

54 The same is true for wider Eastern Europe, cf. Georgiy Kasianov / Philipp Ther, eds, A Laboratory of Transnational History. Ukraine and Recent Ukrainian Historiography, Budapest, New York 2009.

55 Over 260,000 Albanians in Macedonia Vote in Referendum in Favor of the Agreement, Oculus News, 1 October 2018, http://www.ocnal.com/2018/10/over-260000-albanians-in-macedonia-vote.html. 
imaginations of allegedly homogenous ethnic nations and their prospective states, which have always overlapped.

To be sure: If the agreement of Lake Prespa - which has the support by the necessary two-thirds of the members of the Macedonian parliament, which would also overrule a veto by the president-can help overcome the blocked status of Macedonia in its accession talks to the European Union, it should be supported. This is the case even if one takes into account that the relevant majority in parliament was achieved with the votes of members of VMRO-DPMNE. These may have supported the bill only in exchange for letting escape to Hungary the former, and convicted, president of the country, Nikola Gruevski. The agreement foresees, however, the establishment of a commission of international experts tasked with enforcing the paragraphs discussed here even in school textbooks:

'Within one month of the signing of this Agreement, the Parties shall establish by exchange of diplomatic notes, on a parity basis, a Joint Inter-Disciplinary Committee of Experts on historic, archaeological, and educational matters, to consider the objective, scientific interpretation of historical events based on authentic, evidence-based and scientifically sound historical sources and archaeological findings. The Committee's work shall be supervised by the Ministries of Foreign Affairs of the Parties in cooperation with other competent national authorities. It shall consider and, if it deems appropriate, revise any school textbooks and school auxiliary material such as maps, historical atlases, teaching guides, in use in each of the Parties, in accordance with the principles and aims of UNESCO and the Council of Europe. To that effect, the Committee shall set specific timetables so as to ensure in each of the Parties that no school textbooks or school auxiliary material in use the year after the signing of this Agreement contains any irredentist/revisionist references. ${ }^{56}$

The members of such a gremium will most certainly find themselves in quite an uncomfortable situation, as nothing less is asked from them than to negate the most basic theoretical and methodological knowledge concerning national myth-making, the constructed nature of ethnicity, the meaning of (trans)cultural practices, and the potential inherent in developing and promoting concepts of political citizenship.

\section{CORRESPONDING AUTHOR}

Stefan Rohdewald Justus-Liebig-Universität Gießen, Historisches Institut, Osteuropäische Geschichte, Otto Behaghel Strasse 10, 35394 Gießen, Germany. E-mail: stefan.rohdewald@geschichte.uni-giessen.de

56 Excerpt from article 8, paragraph 5: The Prespa Agreement, https://vmacedonia.com/ politics/macedonia-greece-agreement.html. 